\title{
Unprecedented but not Unpredictable: Effects of the COVID-19 Crisis on Commodity-Dependent Countries
}

\author{
Bernhard Tröster $^{1}$ (D) Karin Küblböck $^{1}$
}

Accepted: 7 October 2020 / Published online: 21 October 2020

(c) European Association of Development Research and Training Institutes (EADI) 2020

\begin{abstract}
The global spread of COVID-19 represents a massive challenge for developing countries. Beyond the health crisis and the sudden stop of domestic economic activities, many countries face turmoil linked to commodity dependence. Commodity prices have reacted strongly to the crisis, reflecting changes in supply and demand due to policy measures to limit contagion. Commodity-dependent developing countries are therefore confronted with an unprecedented combination of shocks. However, the crisis has also exposed structural vulnerabilities of these countries linked above all to commodity price dynamics. In the context of a longstanding debate on commodities and development, we portray recent commodity price developments and underlying drivers and discuss implications for commodity-dependent countries, including the risks of depressed export earnings and of changing global production patterns in the long run. Responses to the crisis have to include measures to stabilize commodity prices as well as strategies for economic diversification.
\end{abstract}

Keywords Commodities $\cdot$ Commodity dependence $\cdot$ Resource curse $\cdot$ Commodity prices $\cdot$ Diversification $\cdot$ Price stabilization $\cdot$ COVID-19

\section{Résumé}

La propagation mondiale de la COVID-19 représente un défi majeur pour les pays en développement. Au-delà de la crise sanitaire et de l'arrêt brutal des activités économiques nationales, de nombreux pays sont confrontés à des problèmes liés à leur dépendance à l'exportation des produits de base. Le prix des produits de base a réagi fortement à la crise, reflétant les changements dans l'offre et la demande liés aux mesures politiques visant à limiter la propagation du virus. Ces chocs, combinés à une contraction économique à l'échelle nationale et internationale, sont sans précédent. Cependant, la crise a également mis en évidence les vulnérabilités struc-

Bernhard Tröster

b.troester@oefse.at

Karin Küblböck

k.kueblboeck@oefse.at

1 Austrian Foundation for Development Research (ÖFSE), Sensengasse 3, 1090 Vienna, Austria 
turelles des pays en développement qui dépendent de l'exportation des produits de base - vulnérabilités liées avant tout à la dynamique des prix des produits de base. Dans le cadre d'un débat de longue date sur les produits de base et le développement, nous mettons en lumière l'évolution actuelle du prix des produits de base ainsi que les facteurs sous-jacents de cette évolution, et en évoquons les implications pour les pays qui en dépendent. Ces implications incluent le risque d'une baisse des recettes d'exportation et d'un changement de modèle de production mondiale sur le long terme. Les réponses à la crise doivent inclure des mesures de stabilisation des prix des produits de base ainsi que des stratégies de diversification économique.

\section{Introduction}

Commodity dependence is a persistent characteristic of most developing economies. Two-thirds of developing countries are commodity export-dependent, as commodities account for more than $60 \%$ of their total merchandise exports. Also, almost $60 \%$ are commodity-dependent on the import side, with commodities accounting for at least $30 \%$ of their total merchandise imports. Moreover, revenues obtained from commodity extraction and exports are key for financing imports and public spending in commodity-dependent developing countries (CDDCs) (Nkurunziza et al. 2017; UNCTAD 2019a). The predominant role of commodities creates complex and diverse vulnerabilities for these countries. As highlighted in the debates around the 'resource curse', the high dependence on primary commodities goes hand in hand with depressed economic and human development (Van der Ploeg and Poelhekke 2017).

The global spread of COVID-19 has led to the sharpest economic decline since World War II and has affected all countries in unprecedented ways. Commoditydependent countries are, however, impacted in multiple and specific ways: First, lockdown measures in many countries around the world brought global mobility and transportation to a hold and disrupted highly interdependent global supply chains, depressing the demand for oil and minerals. Second, prescribed closure of businesses, as well as shrinking income due to higher unemployment, depresses the global demand for manufactured goods, which are based on commodities. Third, the COVID-19 outbreak in commodity-producing countries has led to closures of mines, for instance in Peru or South Africa, and to interruptions in agriculture, directly affecting the supply of these commodities. Fourth, similar to other global crises, uncertainty has led to massive outflows of capital from emerging markets towards "safe havens". All these factors have contributed to sharp declines and high volatility in commodity prices, and exchange rates and thereby to large macroeconomic uncertainties for these countries (World Bank 2020). Thus, CDDCs face the risk that the turmoil in the commodity sectors, the domestic economic slowdown, and the health crises create multiple crisis that mutually reinforce each other and exceed the capacities of these countries for a proper response.

Even if the COVID-19 crisis represents an unprecedented combination of shocks with substantial impacts on both the demand and supply of commodities and results in complex effects in the specific countries, the potential vulnerabilities of CDDCs 
were not unpredictable. As high commodity dependence creates negative effects for economic and human development via several channels, such as declining and fluctuating terms of trade, changes in real exchange rates and public revenues and spending (Nkurunziza et al 2017), these transmission channels and their effects can be identified in the current crisis. These interrelations also underline, why the downward trend in average commodity prices since 2012, has led to an economic slowdown, a worsening fiscal situation and rising external debt levels in many of these countries already ahead of the COVID-crisis.

Since March 2020, an increasing number of reports, mainly from international organizations, deal with analysing impacts of COVID-19 on developing countries, including the effects on commodity sectors (IDB 2020; OECD 2020b, 2020a; UN DESA 2020; UN ECLAC 2020b). However, a contextualization of current developments in the long-lasting debate on commodity dependence is lacking. We, therefore, provide an overview of COVID-related commodity supply and demand shocks as well as commodity price developments based on current reports and data. We link our discussion about the effects of COVID-19 on commodity-dependent countries in the short to long run with debates about commodity dependence and development, transmission channels and the resource curse. We highlight in particular, the key role of commodity price dynamics and price determination on global commodity markets and underline the need for policies and measures for price stabilization and the diversification of the economic structure in CDDCs.

The remainder of this article is organized as follows. "Commodity Price Dynamics and the "Resource Curse"" presents the debate about the effects of commodity dependence on economic development, with a focus on the key role of commodity price dynamics. "Commodity Markets in the COVID-19 Crisis" presents commodity price changes in the effects of COVID-19 crisis and assesses the underlying divers of these commodity price changes, including dynamics on commodity financial markets. "Implications for Commodity-Dependent Countries in the Global South" highlights the effects for CDDCs and "Policy Areas for Coping with Price Volatility and the Resource Curse" discusses the implications of the current crisis for the debate around commodity dependence, before we conclude.

\section{Commodity Price Dynamics and the 'Resource Curse'}

The link between a country's natural resources and development outcomes has been the subject to longstanding debates in development economics. Key questions are the capacity of commodity sectors to generate dynamic growth and whether growing commodity sectors benefit or harm the development of the manufacturing and modern service sectors and thereby undermine diversification and structural transformation (Ocampo 2017). Many post-war development theories still assigned a crucial role to returns from commodity extraction as a means for economic transition (Rostow 1960; Rosenstein-Rodan 1961). However, in the aftermath of the boom-bust cycle of commodities in the 1970s, scientific attention focused on the interconnection between commodity sectors and deindustrialization, mainly via the channel of a real exchange rate shock, denominated as 'Dutch Disease' (Corden and 
Neary 1982). Building on these theoretical models and country case studies (Gelb 1988; Auty 1990), the thesis of the 'resource curse' gained prominence in the 1980s and 1990s, asserting an inverse relationship between natural resources and economic development (Auty 1993). Auty's assumptions were supported by empirical findings of Sachs and Warner (2001) on adverse growth effects linked to an initial high share of mineral and energy exports. Yet, positive voices on commodity-based development were raised again in the context of the commodity boom in the 2000s and upgrading within global value chains (Morris et al. 2012; Kaplinsky and Morris 2016). Over the last decades, many scholars have emphasized the complexities of economic and political transmission mechanisms and the conditionalities of the 'curse' (see literature survey in Gilberthorpe and Papyrakis 2015; Van der Ploeg and Poelhekke 2017).

Commodity price dynamics feature arguably as the key mechanism in these debates to explain the direct and indirect impacts of commodity dependence on economic growth and development outcomes. ${ }^{1}$ Moreover, commodity price behaviours are crucial for the analysis of short- and long-term perspectives on the macroeconomic effects of commodity dependence (Deaton 1999; Ocampo 2017). The Prebisch-Singer thesis (Prebisch 1950; Singer 1950) is a prominent approach that analyses the development of relative prices of commodities vis-à-vis manufactured goods and identifies a long-run deterioration in terms of trade (relative prices of export and import units) for countries exporting primary commodities. Accordingly, commodity dependence creates a persistent disadvantage for commodity-exporting countries in their trade relations with industrialized countries due to low-income elasticity of demand for primary commodities, asymmetric power relationships in favour of developed countries and an asymmetric division of benefits related to productivity improvements. If true, this implies the need for pro-industrialization strategies as stated by Prebisch (1950). Empirical evidence generally supports the validity of the Prebisch-Singer hypothesis on a negative trend in terms of trade for commodityexporting countries in the long run, even though with different intensities for different commodities and periods (Harvey et al. 2010; Erten and Ocampo 2013; Baffes and Etienne 2016).

Besides these long-term trends, commodity-dependent countries are confronted with short-term and cyclical fluctuations, mainly driven by commodity price dynamics which in turn affects long-term growth prospects. Several transmission channels of adverse effects of price fluctuations on economic development have been identified in the literature: The first strand of literature is concerned with the short-term price fluctuations creating external stress for CDDCs and hence macroeconomic instability and adverse growth effects. In particular, external shocks in terms of trade (Easterly et al. 1993) and terms of trade volatility (Cavalcanti et al. 2015) have been identified as an important determinant for long-term growth differentials. Other studies establish a more direct link to commodity prices. Van der Ploeg and Poelhekke (2009) see commodity price volatility as the primary cause for

\footnotetext{
1 The resource curse literature also includes debates on political and social effects, but we focus on economic impacts here.
} 
the resource curse by leading to unanticipated GDP fluctuations with adverse longterm effects on output growth. In this line, Fernández et al. (2017) show that price shocks explain on average one-third of output fluctuations in individual economies and even two-thirds since 2000. A further transmission channel of commodity price volatility on economic development is government spending, as fiscal income often heavily relies on commodity extraction and exports. Fluctuating commodity prices hence create fiscal imbalances and volatility in public spending (UNCTAD and FAO 2017). In many cases, commodity-dependent countries experience pro-cyclical patterns of fiscal spending, investment and consumption (Humphreys et al. 2007).

Another debate focuses on 'dutch disease' effects and more generally on the negative effects of commodity dependence on the development of manufacturing sectors through changes in real exchange rates. While the static model by Corden and Neary (1982) introduced the adverse effects of spending-induced exchange rate appreciation on the competitiveness of non-commodity sectors, the concept of 'dutch disease' has been increasingly used more broadly and the term is now a synonym for "the failure of commodity-abundant economies to promote a competitive manufacturing sector" (Sarraf and Jiwanji 2001, p. 3). The behaviour of real exchange rates remains key in this discussion, and Gylfason et al. (1999) argue that the 'dutch disease' can be explained by volatility in real exchange rates, which is harmful for physical investment and the accumulation of human capital and related 'learning by doing' effects. Ocampo (2017) emphasizes that changes in real exchange rates are generated by commodity price booms and busts.

Many developing economies are also dependent on commodity imports, mainly on food and fuels. The volatility of import-commodity prices, therefore, further increases the vulnerability of those countries and adds to the complexity of the resource curse analysis on the macroeconomic level. It also affects the sector and micro level. On the one hand, millions of smallholders depend strongly on export earnings from cash crops, on the other hand, these households spend a large share of their income on food, which is often imported, and they might use fuels and fertilizers. Further, urban households in developing countries are generally net food buyers. Thus, these effects on the household level can be highly diverse within a country (von Arnim et al. 2018), and the volatility of food and fuels price creates substantial risks in the short-term, including hunger, and can lead to adverse long-run effects, for instance when expenditures on health and educations have to be reduced (UNCTAD and FAO 2017).

More general, the quality of institutions has been identified as an important factor for the resource curse (van der Ploeg 2011; Epo and Nochi Faha 2020). In particular, missing fiscal rules for counter-cyclical spending mechanisms, rent-seeking and corruption have been identified as indicators for 'bad resource governance' (Badeeb et al. 2017). Policy advice to CDDCs has consequently been to strengthen the rule of law, as well as fiscal and monetary policies to manage variations in public spending and exchange rates and to increase transparency (Gilberthorpe and Rajak 2017). While good institutions and good governance are undoubtedly key to manage large swings in macroeconomic variables, there is a potential mismatch between policy advices on governance and capacities of CDDCs to follow it (Lahn and Stevens 2018). In particular, political-economic challenges of state-capacity building, 
historical trajectories and power relations have to be considered (Colom-Jaén and Campos-Serrano 2013; Gilberthorpe and Rajak 2017).

Finally, the debate around the resource curse and potential solutions have to take into account the limits of national policy options, given that terms of trade shocks and volatility are exogenous from the perspective of individual countries, as commodity prices are determined on a global level (Gruss and Kebhaj 2019). Thus, individual CDDCs can use policies to mitigate these external shocks as a second-best solution but have to deal with more severe and more frequent shocks than developed counties (UNCTAD and FAO 2017). Moreover, world commodity prices are typically determined on commodity derivatives markets, in which financial investors have gained a dominant role over the last decade, known as 'financialization of commodity markets' (Ederer et al. 2016). Thus, the dynamics of world commodity prices, including excess volatility and short-term price variation, has been influenced by activities financial actors (Cheng and Xiong 2014; Adams et al. 2020). As these futures prices are used as the benchmark for all other prices set along physical commodity chains, the behaviour of financial investors in the current crisis plays a crucial role in the current challenges faced by commodity-dependent countries (Staritz et al. 2018).

\section{Commodity Markets in the COVID-19 Crisis}

\section{Commodity Price Dynamics}

Commodity prices have reacted strongly to the COVID-19 crisis with significant variations on a daily and weekly basis from February 2020 onwards and the volatility of all types of commodities increased significantly (Fig. 1). Particular, price hikes and drops in crude oil in March and April 2020 exceeded the variations during the global financial crisis in 2008/2009, but also price variations in metals and agriculture commodities clearly surpassed levels in recent years.

The extent and the direction of price changes differ considerably by commodity depending on the specific end-use sector, the different degree of affectedness by COVID-19 in producer and consumer countries, as well as storability and supply elasticities (IMF 2020b), as shown by the price changes of selected commodity indices from January to August 2020 (Fig. 2). In particular, the prices of energy commodities collapsed in an unprecedented way by as much as $-70 \%$ at the end of April compared to the beginning of 2020 and were still down by - 30\% in August 2020. Also prices of base metals such as copper, iron ore and zinc declined significantly with sharp price drops in March and April 2020 with up to - 20\%, but recovered since May. In contrast, gold prices, as precious metal, benefited in the current uncertainty and the demand from investors and have reached all-time highs. The price developments for individual agricultural products varied widely, with increasing grain prices up to April, and declining prices for plant oils and meat since early 2020.

Commodity prices are generally characterized by price cycles, which are asymmetric as the duration of slumps exceeds the duration of booms (Cashin et al. 2002), 


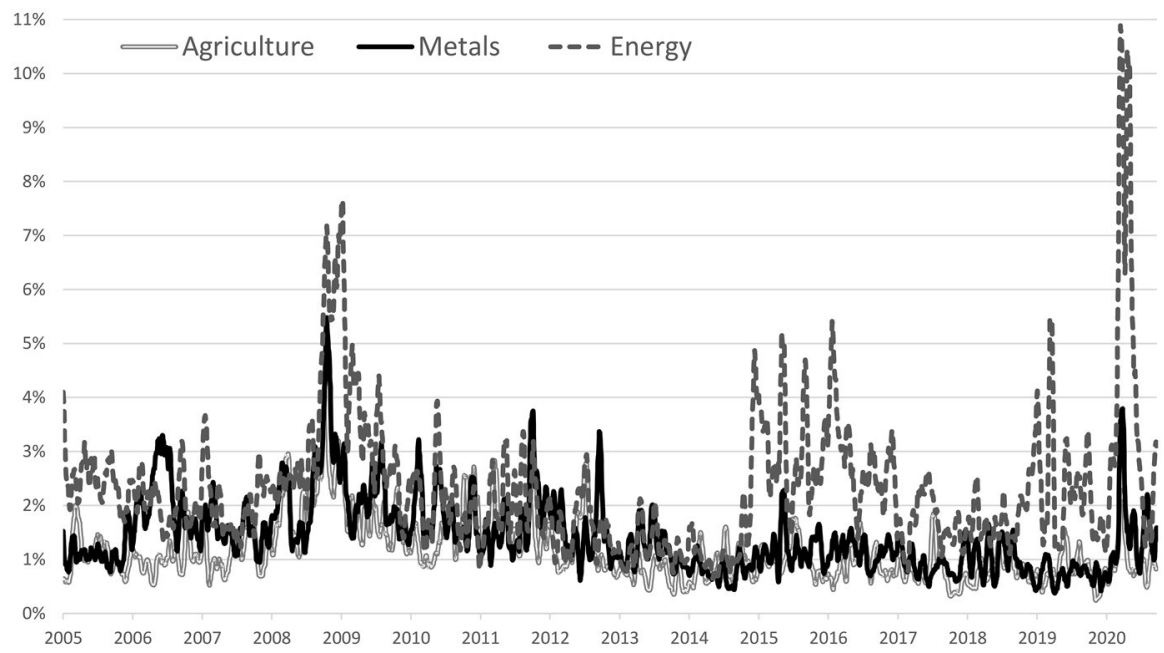

Fig. 1 Volatility of Commodity Price Indices. Note: 20-day rolling average of Coefficient of variation (10 days), own calculations based on daily prices of Euronext Rogers International Commodity Index Agriculture, Metals \& Energy. Source: Rogers International Commodity Index http://www.rogersrawm aterials.com/daily.asp

but such cycles show no regularity or predictability (Jacks 2019). Further, commodity prices show large fluctuations due to fundamental relationships between supply and demand. In particular, the combination of low short-term elasticities of supply and demand with shocks in economic activities or supply creates large price

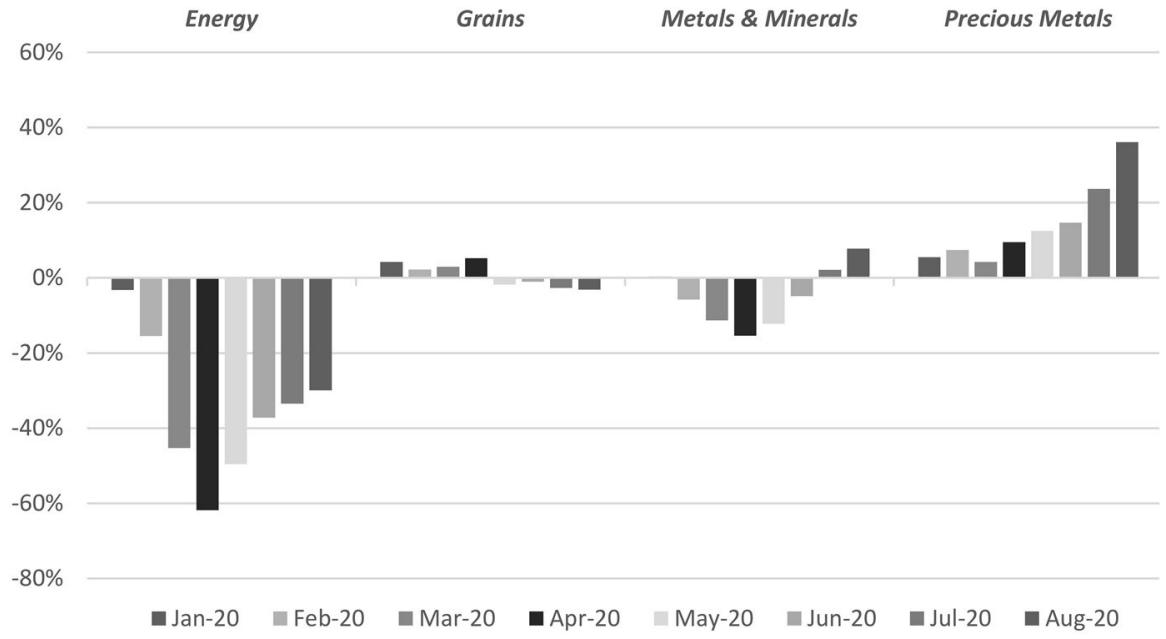

Fig. 2 Price Changes of Selected Commodity Indices relative to December 2019. Source: World Bank Data. https://www.worldbank.org/en/research/commoditymarket 
fluctuations (Deaton 1999). However, the number of boom and bust episodes has increased since the 1970s (Jacks 2019). Above all, the boom period from 2003 to 2011, known as 'commodity super-cycle', and the following high price variations from 2008 to 2011 have been subject to a debate about to what extent these movements are based on fundamental factors or the impact of financial investors (Nissanke 2012; Ederer et al. 2016). In the following section, we identify the drivers of the current dynamics are identified in order assess their potential impact on CDDCs.

\section{Drivers of Commodity Prices in the COVID-19 Crisis}

The commodity price shocks in the COVID-19 crisis so far reflect the simultaneous combination of unique supply and demand factors at national and international levels. In particular, the current decline in oil prices is larger than price drops in previous global recessions (World Bank 2020). The COVID-19 prevention measures lead to very specific supply and demand responses, which have different implications for commodity producers, traders and consumers than in previous crises. Nevertheless, it should be borne in mind that centralized pricing in commodity markets takes place largely in commodity financial markets and is transferred to physical markets through pricing practices in these sectors. Thus, financial dynamics and speculation can influence or even undermine the processing of fundamental demand and supply information in price determination.

The fundamental drivers of the market conditions in early 2020 have been largely related to the lockdown measures introduced in countries around the world in March and April 2020 to contain the spread of corona virus. They have affected both supply and demand through numerous and interconnected channels:

\section{Aggregate Demand Shock}

The sudden breakdown in economic activities has led to a sharp drop in incomes and aggregate demand. The global economy is forecasted to shrink by $-4.9 \%$ in 2020 (IMF 2020b, June Update). In particular, the demand for crude oil and other energy commodities have declined as they are directly and indirectly consumed in almost all sectors across the economy. Base metals such as copper, iron ore or zinc are closely linked to the demand for manufactured goods. Therefore, both types of commodities are highly sensitive to short-term slowdowns in economic activities due to their high-income elasticities (Baffes et al. 2020). But also cash crops such as coffee, cocoa and cotton typically react to slowing global demand.

\section{Disruptions in Manufacturing Global Value Chains}

In the current crisis, global value chains (GVCs) of manufactured goods prove to be highly dependent on the supply of certain inputs. As the processing of most manufactured goods is increasingly fragmented and dispersed across various actors and geographic spaces, the failure of individual suppliers or suppliers from a specific country can disrupt production in these GVCs (UN ECLAC 2020b). As a result, 
demand for commodities such as metals or crude oil (plastics), which serve as the basis for many intermediate goods in these sectors, has fallen.

\section{Closures of Commodity Extraction and Production}

The lockdown and the quarantine measures have forced the production of many commodities to be halted. This affects mining projects, which were temporarily shut down, for example in Peru or South Africa. Thus, the supply of various metals declined in March 2020. MacDonald (2020) has identified disruptions in 275 mine sites in 36 countries, the main developing countries being Peru, South Africa, Chile and Mexico. However, the large majority of those mines had already re-opened until June 2020, among others as mining was declared as an essential economic activity in several countries. On the other hand, the supply reactions on oil markets came belated, as the Organization of Petroleum-Exporting Countries (OPEC) and Russia could not agree on a quick and substantial reduction of extraction in early March. Finally, the agreement to cut oil production by a record of almost 10 million barrels per day (or 10\% of global production) from May onwards appears not to be sufficient to close the gap between demand and supply as oil demand is expected to decline by $10 \%$ for the year as a whole (IEA 2020).

\section{Restricted Mobility of People and Goods}

The aim of reducing personal contacts trough travel bans and stay-at-home orders led to a considerable reduction in travel and other, often cross-border, transport activities. The restricted mobility has wide-reaching and diverse consequences in commodity markets. The demand for fuel for transport, which accounts for twothirds of global oil demand, collapsed (World Bank 2020). In agricultural markets, restrictions on the national and cross-border movement of workers have affected the cultivation and harvesting of crops, including the production of cash crops in countries of the Global South such as bananas (Fairtrade International 2020). On the other hand, various commodities including cash crops such as coffee and cocoa and other tropical fruits have suffered from closure of ports and other transport facilities as well as from the disruptions in the international shipping container markets (Ferraresso 2020).

\section{Trade Restrictions}

In late March, the major rice-consuming and exporting countries Vietnam and India considered export bans as a response to potential supply disruption. Unlike in 2007/08, when these measures had been identified as major drivers in the food price surge (Headey 2011; Tadesse et al. 2014), the current measures have not been put into practice so far. Nevertheless, the risk of potential export bans alone has triggered the fear of global supply shortages in foods and prices for rice and wheat showed large price swings. 


\section{Dynamics on Commodity Financial Markets}

Since the beginning of 2000 , the positions of financial investors and commercial actors in US futures and options markets have been fluctuating strongly. When, for instance, prices of Commodity Exchange (COMEX) copper futures declined by $20 \%$ in March 2020, the open interest (number of contracts not yet settled) dropped by almost $30 \%$ reflecting the uncertainty in these markets. However, the share of Money Managers in total open interest in these copper contracts increased to more than $42 \%$, which is the highest value on record ${ }^{2}$ (CFTC Data).

In particular indicators on trading activities in New York Mercantile Exchange (NYMEX) crude oil futures showed the most extreme values since 2006. This includes one of the largest increase $(17 \%)$ and the largest relative decline $(-17 \%)$ over four weeks in the open interest in these WTI oil futures in March and in May 2020, which were particularly driven by changes in the positions of financial investors (CFTC data). The sharp fall in crude oil prices has attracted investors to speculate on a price rebound and to massively buy exchange-traded funds on oil in March. As these investment vehicles take up long positions in futures contracts with nearby expiry, this strong surge in investment flows had the results that the largest US oil ETF alone held 24\% of all outstanding contracts with expiry in June 2020 at NYMEX (Brower and Meyer 2020). This came simultaneously with the extreme constellation of oversupply and shortage of storage in US oil markets, and oil ETFs had to shift investments to contracts with later expiry dates and sell off contracts closer to expires. As a result, prices of nearby contracts collapsed particularly strong, showing how speculative trading can disrupt an increasingly fragile oil market, while demand is so depressed (Dempsey and Stafford 2020).

\section{Implications for Commodity-Dependent Countries in the Global South}

Many CDDCs were confronted with the COVID-19 crisis while already displaying high levels of macroeconomic instability. After 2011, nominal commodity prices fluctuated around a mid-term downward trend, even though prices of energy and mineral commodities could recover from their lows in 2015/2016. In real terms, the global commodity prices in 2019 corresponded to the price levels before 2005 (World Bank data). The major transmission channels of short-term resource curse effects - terms of trade, real exchange rates and public balances-followed these adverse price trends (IMF 2020a). In particular, oil-exporting countries have experienced a strong deterioration in terms of trade index, which declined from a high of 218 in 2012 to 117 in 2017 (UNCTAD stats; index base 2000). For exporters of minerals the index declined from 189 in 2011 to 163 in 2015 . Even though the terms of

\footnotetext{
2 The US Commodity Futures Trading Commission (CFTC) reports weekly open interest data with details on the type of traders since June 2006 https://www.cftc.gov/MarketReports/CommitmentsofTr aders/HistoricalCompressed/index.htm.
} 
trade indices of these commodity-exporting country have generally increased since 2000 , their fluctuations remain high with a standard deviation of annual changes amounting to $17 \%$ and $9 \%$ for oil-exporting and mineral-exporting countries, respectively. In comparison, the standard deviation in indices of exporters of manufactured goods amounted to $3 \%$. In addition, nominal exchange rates of many CDDCs with floating currency systems deteriorated against the dollar, affecting, in turn, terms of trade and real exchange rates. Since 2011, the indices of the real effective exchange rate of commodity exporters have remained on a high level with values of 131.1 (oil), 113.8 (minerals) and 150.2 (agriculture) in 2017, compared to a decline in the index of high-income countries to 77.3 (UNCATD Stats; index base 2005).

Due to historically low interest rates after the financial crisis and in order to counterbalance their weakening position, many CDDCs have increased their external borrowing, largely in US Dollar (UN DESA 2020). In 2019, external debt in Sub-Saharan Africa amounted to $42 \%$ of GDP and to $48 \%$ in Latin America, compared to level of around 25\% in 2007 in both regions (IMF WEO data). According to UNCTAD (2019b), external debt in 17 selected commodity-dependent countries increased by even more than 25\% of GDP between 2008 and 2017. Also government debt has increased substantially, and consequently, debt service in low-income countries has increased as a percentage of government revenue from $6.6 \%$ in 2010 to $12.2 \%$ in 2018 (OECD 2020b). As a result, most CDDCs found themself in a more detrimental situation at the end of 2019 compared to the situation before the global financial crisis and the related turmoil in commodity prices in 2008. Thus, the simultaneous supply and demand shock in commodity markets at national as well as international levels represent an unprecedented challenge for all CDDCs. In addition to the known drivers and transmissions channels in commodity markets shocks other factors have to be considered in this crisis.

\section{Short-Term Effects}

The current short-term changes in commodity markets and prices due to the COVID-19 crisis have been transmitted to CDDCs, even though outcomes differ due to the diverse effects in the respective commodity markets, differences in the spreading of the virus and variations in the economic structures in the single CDDCs. Firstly, terms of trade are expected to deteriorate for oil-exporting and mineralexporting CDDCs in 2020. For instance, in 2009, when oil prices declined comparably, the terms of trade index of oil-exporting countries declined by $31 \%$ (UNCTAD stats). At the same time, the different reactions in oil and food prices can have some favourable effects for net food exporters and net oil importers. Secondly, drops in export earnings and related capital outflows lead to a depreciation of exchange rates, with adverse effects on external debt, among others. Thirdly, government revenues are declining due to lower commodity prices and export volumes as well as due to lockdowns in production and extraction.

The COVID-19 crisis has hit many CDCCs both through price and volume channels via exports. In Latin America, the crisis accelerated the already-existing downward 
trend in exports and many countries were affected particularly hard at an early stage due to the high concentration on commodities and close ties with China that started the lockdown before other regions (IDB 2020). In Peru, for instance, the total exports in March and April 2020 declined by 29\% and 56\%, respectively, compared to the monthly values in 2019, as the export volumes and values of copper contracted significantly. Concomitantly, many African countries such as Zambia or South Sudan that are heavily dependent on commodity exports to China were hit early by the crisis. The historical collapse of oil prices is a major shock for many Africa countries, giving that oil rents represent $4.5 \%$ of the GDP of the continent. For example, in Nigeria, oil represents more than $90 \%$ of exports, and more than $70 \%$ of the national budget (OECD 2020a).

Falling commodity prices have not only weakened external current account balances but also triggered massive capital outflows. During March 2020 alone, capital outflows from developing countries exceeded total capital outflow of capital during the whole year of 2008 (UN DESA 2020). In addition, while there is a significant slowdown across all FDI components, the energy and materials sector are among the most affected, which are particularly relevant for commodity-exporting countries. OECD projections indicate that-in the most optimistic scenario-global FDI will drop by at least $30 \%$ in 2020 , with flows to developing economies likely to fall more strongly (OECD 2020a). While after the financial crisis in 2008, global FDI had dropped with a lag of one year and affected developed countries more than developing countries, this time the impact will be immediate and will hit the weakest country hardest (OECD 2020a).

Deteriorating commodity prices combined with capital outflows has led to an exchange rate depreciation in commodity-exporting countries. For example, in the first quarter of 2020, the Brazilian, Mexican and South African currencies depreciated about 30\% against the dollar. Combined with sharp increases of spreads on developing country bonds, this makes it increasingly costly for those countries to service their external debt.

While the collapse of global and domestic economic activity affects all major sources of government revenues in all countries, resource-rich countries, which derive a large share of tax and non-tax revenues from commodities, will be additionally affected by drops of export volumes and prices. For example, in Latin America, government revenues from non-renewable natural resources amount to $18 \%$ of GDP (UN ECLAC 2020a). In addition, pre-crisis government revenues relative to GDP are low compared to OECD countries (e.g. 22\% in Latin America and 17\% in Africa, respectively), which caps public spending to fight the health and economic crisis. Hence public deficits and debt levels are likely to increase significantly.

\section{Medium-Term Effects}

Beyond described short-term effects, COVID-19 will also affect CDDCs in a medium and long-term perspective. Even in optimistic IMF scenarios about the evolution of global GDP in 2021 which assume that the pandemic will fade out in 2020 and that there is sufficient policy support for recovery (IMF 2020b, p. 4), commodity 
prices are expected to remain at low levels in the coming years. Crude oil prices, for example, are projected at USD 38 per barrel in 2021 and to remain below USD 50 per barrel in the years thereafter (IMF 2020b, p. 18).

Consequently, commodity-exporting countries could be hit twice in the medium term, as lower and stagnating prices could generally lead to a reduction of extractive activities. For OPEC countries, the price reactions to their cuts in oil supplies depend heavily on the response of non-OPEC countries such as the US and Russia. Therefore, lower output might not correspond with higher prices to stabilize export earnings. While in metal markets, mineral-rich countries in Latin America were partially able to compensate for declining prices between 2011 and 2015 by increasing the volume of copper and iron ore exports (UN Comtrade data), weak global demand might limit this option in the coming years. A further extension of mining activities would also come at the cost of increasing environmental deterioration and social tensions.

On the import side, lower prices for fuels and other oil-based products such as fertilizers could ease the pressure on current accounts. Positive effects for sectors and households that use these imported inputs could, however, be limited, given that lower incomes and depressed economic activity in most countries would curb demand despite lower prices. In addition, the import of processed commodities requires that supply chains are not disrupted, and shut-downs of major refineries and other processing facilities could drive price wedges between raw and processed materials.

Essential risks emerge from the development of food prices. So far, global food prices have been relatively stable, with some exceptions on the upside (rice) and on the downside (maize, plant oils). This means for net-food importing countries, that expenditures on food imports are not likely to decline, while they are confronted with lower export earnings and exchange rate depreciation. In addition, disruptions in the supply chain, storage or transportation can drive local food prices above global levels and might lead to food-exporting countries introducing export restrictions. In sum, there are substantial risks that the COVID-19 crisis could easily trigger a food crisis, in particular in Sub-Saharan African countries (FAO 2020).

\section{Long-Term Effects}

COVID 19 has exposed the vulnerabilities of the current model of globalization based on highly fragmented and interdependent global production systems and could lead to significant changes in the global organization of production. According to the World Bank (2020), the disruption of supply chains and changing consumer behaviour as a response to calls for more regional and local products could reduce the demand for commodities of CDDCs in the long run. Certain sectors that are relevant for CDDCs such as agribusiness or horticulture might be re-shored to be closer to final markets (OECD 2020a). Debates are intensifying that policy responses to COVID-19 have to increase sustainable development efforts such as decreasing resource consumption and increasing circularity of developed economies (European Commission 2020). The pandemic may also reinforce existing trends towards less 
trade interdependence among the world's major economies, and towards regionalization processes (UN ECLAC 2020b). Consequently, commodity exporters might face negative impacts on demand for their commodities and hence their current and fiscal accounts but the development could also be seen as an opportunity to diversify their economic structure and to increase regionalization efforts.

\section{Policy Areas for Coping with Price Volatility and the Resource Curse}

The current crisis highlights once more that dependence on commodities is a major limiting factor to economic and human development for many countries. The insights from price fluctuations and the impacts on CDDCs as well as from trade and global supply chain disruptions in the course of the COVID-19 crisis so far should be considered as an occasion to discuss policy options to fight the resource curse. As elaborated in Sect. 2, commodity price dynamics are the key factor to explain the adverse effects of commodity dependence on economic growth and human development through different transmission channels. The determination of world commodity prices is, however, exogenous from the perspective of the individual CDDCs. This implies that public and private actors in CDDCs must have the capacity to manage large, short-term fluctuations causing macroeconomic uncertainties, while facing the risk of long-term, structural asymmetries. Therefore, two major policy areas are highly relevant in this context: commodity price stabilization and the diversification of CDDCs' export baskets and economic structures.

\section{Commodity Price Stabilization}

Concerning commodity price stabilization, the institutional and policy context has changed significantly since the 1980s and 1990s from stabilization of commodity prices and export earnings in producer countries to liberalization and marked-based instruments for price setting and price risk management (PRM) (Nissanke 2017). At the global level, international commodity agreements (ICAs) were established in the 1950s and 1960s between producer and consumer countries to stabilize commodity prices employing minimum price systems, buffer stocks, and export quotas. Thus, price determination in this context has been influenced actively by public actors in producer and consumer countries. At the national level, many commodity-producing countries ran national price stabilization mechanisms, in particular for cash crops, supported by compensatory financing schemes by the IMF and the EU (STABEX for agricultural products and SYSMIN for mining products) to ameliorate the adverse effects of fluctuating export earnings (Staritz et al. 2018).

As ICAs were dismantled by the end of the 1980s due to economic and political reasons, most domestic price stabilization mechanisms in commodity sectors were removed in a general shift to market liberalization (Gilbert 1996). Commodity derivative markets emerged as the dominant, exogenous centres for pricing and risk management mechanism for international commodity trade (Nissanke 2012). However, with the deregulation of these commodity derivatives exchanges in the 
early 2000s, the structure of actors active on these markets has changed and financial investors have emerged as the dominate type of trade ("financialization of commodity markets'). Thus, the level and the volatility of world commodity prices are increasingly influenced by financial market dynamics (Adams et al. 2020). Further, the organization of global commodity chains, in which commodities are trade and prices are transmitted from the global to the local level, has changed towards the governance by transnational buyers and traders (Staritz et al. 2018).

After the 2008/2009 commodity boom and bust, international initiatives have been formulated (see the Interagency Report to The G20 On Food Price Volatility in 2011 (FAO 2011)) and potential stabilization mechanisms have been presented to address excess volatility of commodity prices and the impact of financial actors (Ocampo and Griffith-Jones 2007; von Braun and Torero 2009). However, the political actions to tackle speculation by financial investors have failed to materialize or proved to be difficult to implement as the example of potential position limits for traders in derivative markets in the US (Meyer 2020) and the EU show (ESMA 2020).

Given the persistent resistance to interventions in financial markets and global price stabilization mechanisms, cooperation on the regional level could gain significance. Examples are national and regional stabilization funds and initiatives for smallholders producing cash crops such as cotton and cocoa in West Africa, in particular the initiative of Ghana and Côte d'Ivoire that is currently implemented to raise minimum prices for cocoa farmers (Tröster et al. 2019). Such schemes can potentially enable countries to counterbalance weak bargaining power against dominant international buyers, but the functioning of these stabilization mechanisms are exposed to the high volatility of global commodity prices.

Many oil- and mineral-rich developing countries have introduced sovereign wealth funds (SWFs) in recent years to balance governmental expenditures and provide intergenerational savings accumulation, buffers against economic shocks, wealth diversification, and funding for domestic investment. However, the record of SWFs is mixed given the differences in the quality of public financial-management systems, but also due to excessive commodity price volatility as newly established SWFs might not be equipped with sufficient funds to balance extreme one-time price drops or episodes of prolonged price decline (Tröster 2018). The current crisis also shows the risks created by interdependencies between financial asset prices, commodity prices and the value of SWFs (Arnold 2020). Therefore, regional or international counter-cyclical financing facilities could be crucial elements to support mechanisms to mitigate income shocks from commodity price movements and to ensure the financing of national price stabilization schemes and policy space for counter-cyclical macroeconomic measures. These mechanisms could be further enhanced with the support of regional or international development banks.

\section{Economic Diversification}

The second policy area refers to the need for a diversification of CDDCs' export baskets and economic structures. As terms of trade shock and volatility are externally 
determined, this channel of transmission can only be narrowed by a reduced weight of commodities in exports and imports (UNCTAD and FAO 2017). However, the persistence of commodity dependence and the intense debate around export diversification, upgrading and industrialization in development economics show the major challenges to achieve this goal (Stiglitz and Lin 2013; Rodrik 2018). Further, regional and sectoral differences have been identified in this context (see Ocampo et al. 2009 on Latin America; and Whitfield et al. 2015 on Africa).

One strand of the literature focuses on the role of commodity sectors within this catching-up process in a 'commodity-based development' (Morris et al. 2012). This approach is on the one hand focused on upgrading into higher value-added production activities, which would also imply the export of products that are less dependent on world commodity prices. The concept of upgrading is essential in the literature on Global Value Chains and Global Production Networks (Gereffi et al. 2005; Coe and Yeung 2019), and various scholars have analysed upgrading potentials of lowincome countries in commodity sectors (Gibbon and Ponte 2005; Grumiller 2018). On the other hand, structural transformation can be understood as a process of linkages development (Hirschmann 1981). This involves forward linkages to processing with important potential for value addition and employment generation as well as backward linkages in terms of input provision including equipment and services from information technology to transport (Fessehaie and Morris 2013). Therefore, Kaplinsky and Morris (2016) emphasize the distinction between vertically specialized GVCs and additive GVCs in the process of structural change.

A second part of this discussion on structural change and diversification focuses on latecomer industrialization and on the prospects of low-income countries to replicate the Asian example of export-oriented growth through foreign direct investment, taking light manufacturing as a starting point for industrial-led economic development. This policy approach has been discussed for instance for countries in Sub-Saharan Africa. However, the challenges to successfully integrate into niches of GVCs shows to be highly challenging, given that many East Asian countries have forwarded this approach and that GVCs are governed by TNCs, which creates a highly competitive environment for such activities. Therefore, Frankema and van Waijenburg (2018) see low wage cost advantages in African countries compared to China and a weak proto-industrial foundation as major barrier for such a development path and suggest a focus on domestic market integration. Also the potential of 'leapfrogging' manufacturing for a services-led strategy is discussed (Behuria and Goodfellow 2019).

Despite these challenges for diversification, the current COVID-19 crisis emphasizes the need for a policy strategy to lower the dependence on commodities. If taken seriously, the discussion on restructuring GVCs and the reduction of material consumption in high-income countries (as discussed in section 4) would make it more difficult to maintain a commodity-dependent development model. However, such processes require a long-term perspective and a broad set of industrial policies and capacities in the public and private sector and sufficient policy space in CDDCs as well as political support from countries of the Global North. The focus on price stabilization and diversification does not imply that fiscal and monetary policies in CDDCs are less relevant. On the contrary, the management of volatile public 
revenues and exchange rate is an immediate task for CDDCs, even though their successful application is a major challenge even for high-income countries with natural resources (van der Ploeg 2016; Bjørnland and Thorsrud 2019). The success of these policy measures depends on the dynamics of commodity prices, political-economic factors and power relations in the global production networks through which global prices are transmitted to local actors.

\section{Conclusions}

The global spread of COVID-19 represents a massive challenge for developing countries. Beyond the health crisis, and an economic crisis due to lockdown measures, many countries face additional economic turmoil linked to their dependence on commodities. Commodity markets have reacted strongly to the COVID-19 crisis with price movements, reflecting changes in supply and demand in commodity markets due to the policy measures to contain the pandemic, but also due to activities of financial actors on commodity derivative markets. The combination of simultaneous supply and demand shocks with economic contraction at the domestic and international level is unprecedented. The concrete outcomes on CDDCs and the role of underlying factors have to be the subject to future research once sufficient data are available.

In addition, the crisis has once more exposed structural vulnerabilities of commodity-dependent developing countries. This negative relation between commodity dependence and economic and human development is linked above all to declining terms of trade and the volatility of global commodity prices, which are largely determined on commodity futures markets, and therefore exogenous to CDDCs. To reduce adverse effects of commodity price developments on CDDCs, first, international, regional, and national price stabilization measures are needed, and second economic diversification has to reduce the importance of commodities in exports and imports—and hence prices_-for the economic and human development.

\section{References}

Adams, Z., S. Collot, and M. Kartsakli. 2020. Have commodities become a financial asset? Evidence from ten years of Financialization. Energy Economics 89: 104769.

Arnold, T. 2020. Oil-rich wealth funds seen shedding up to $\$ 225$ billion in stocks. Reuters. https://www. reuters.com/article/us-health-coronavirus-swf-analysis-idUSKBN21G05K.

Auty, Richard M. 1990. Resource-based industrialization: Sowing the oil in eight developing countries. New York: Oxford University Press.

Auty, Richard M. 1993. Sustaining development in mineral economies: The resource curse thesis. London: Routledge.

Badeeb, R.A., H.H. Lean, and J. Clark. 2017. The evolution of the natural resource curse thesis: A critical literature survey. Resources Policy 51: 123-134.

Baffes, J., and X.L. Etienne. 2016. Analysing food price trends in the context of Engel's Law and the Prebisch-Singer hypothesis. Oxford Economic Papers 68 (3): 688-713.

Baffes, J., A. Kabundi, and P. Nagle. 2020. The role of income and substitution in commodity demand. Washington, DC: The World Bank. 
Behuria, P., and T. Goodfellow. 2019. Leapfrogging manufacturing? Rwanda's attempt to build a services-led "developmental state". The European Journal of Development Research 31 (3): 581-603.

Bjørnland, H.C., and L.A. Thorsrud. 2019. Commodity prices and fiscal policy design: Procyclical despite a rule. Journal of Applied Econometrics 34 (2): 161-180.

Brower, D., and G. Meyer. 2020. World's largest oil ETF revamps portfolio after market chaos. Financial Times. https://www.ft.com/content/11cf8aeb-2d74-4c25-a111-943be6d8bf39.

Cashin, P., C.J. McDermott, and A. Scott. 2002. Booms and slumps in world commodity prices. Journal of Development Economics 69 (1): 277-296.

Cavalcanti, T., K. Mohaddes, and M. Raissi. 2015. Commodity price volatility and the sources of growth: Commodity price volatility and the sources of growth. Journal of Applied Econometrics 30 (6): $857-873$.

Cheng, I.-H., and W. Xiong. 2014. Financialization of commodity markets. Annual Review of Financial Economics 6 (1): 419-441.

Coe, N.M., and H.W. Yeung. 2019. Global production networks: Mapping recent conceptual developments. Journal of Economic Geography 19 (4): 775-801.

Colom-Jaén, A., and A. Campos-Serrano. 2013. Oil in Chad and equatorial guinea: Widening the focus of the resource curse. The European Journal of Development Research 25 (4): 584-599.

Corden, W.M., and J.P. Neary. 1982. Booming sector and de-industrialisation in a small open economy. Economic Journal 92 (368): 825-848.

Deaton, A. 1999. Commodity prices and growth in Africa. Journal of Economic Perspectives 13 (3): $23-40$.

Dempsey, H., and P. Stafford. 2020. US crude prices tumble as world's largest oil ETF cuts stake. Financial Times. https://www.ft.com/content/a8a7dc16-1a9a-48f9-9bfa-89269f94218a.

Easterly, W., M. Kremer, L. Pritchett, and L.H. Summers. 1993. Good policy or good luck? Journal of Monetary Economics 32 (3): 459-483.

Ederer, S., C. Heumesser, and C. Staritz. 2016. Financialization and commodity prices-An empirical analysis for coffee, cotton, wheat and oil. International Review of Applied Economics 30 (4): 462-487.

Epo, B.N., and D.R. Nochi Faha. 2020. Natural resources, institutional quality, and economic growth: An African tale. The European Journal of Development Research 32 (1): 99-128.

Erten, B., and J.A. Ocampo. 2013. Super cycles of commodity prices since the mid-nineteenth century. World Development 44: 14-30.

ESMA. 2020. MiFID II Review report on position limits and position management. European Securities and Market Authority.

European Commission. 2020. A new circular economy action plan. For a cleaner and more competitive Europe. (COM (2020) 98 final).

Fairtrade International. 2020. Fairtrade together: COVID-19 briefing on 27 April 2020. Fairtrade International. https://www.fairtrade.net/news/fairtrade-together-covid19-briefing-on-27-april-2020.

FAO. 2011. Interagency Report to the G20 on Food Price Volatility. FAO, IFAD, IMF, OECD, UNCTAD, WFP, the World Bank, the WTO, IFPRI and the UN HLTF.

FAO. 2020. COVID-19: Our hungriest, most vulnerable communities face "a crisis within a crisis." http://www.fao.org/news/story/en/item/1269721/icode/.

Fernández, A., S. Schmitt-Grohé, and M. Uribe. 2017. World shocks, world prices, and business cycles: An empirical investigation. Journal of International Economics 108: 2-14.

Ferraresso, J. 2020. How COVID-19 May affect the chain as Brazil heads into harvest. Daily Coffee News by Roast Magazine, 27th April. https://dailycoffeenews.com/2020/04/27/how-covid-19-may-affec t-the-chain-as-brazil-heads-into-harvest/.

Fessehaie, J., and M. Morris. 2013. Value chain dynamics of chinese copper mining in Zambia: Enclave or linkage development? The European Journal of Development Research 25 (4): 537-556.

Frankema, E., and M. van Waijenburg. 2018. Africa rising? A historical perspective. African Affairs 117 (469): 543-568.

Gelb, A.H. 1988. Windfall gains: Blessing or curse?. New York: Oxford University Press.

Gereffi, G., J. Humphrey, and T. Sturgeon. 2005. The governance of global value chains. Review of International Political Economy 12 (1): 78-104.

Gibbon, P., and S. Ponte. 2005. Trading down. Philadelphia, PA: Temple Univ. Press.

Gilbert, C.L. 1996. International commodity agreements: An obituary notice. World Development 24 (1): $1-19$. 
Gilberthorpe, E., and E. Papyrakis. 2015. The extractive industries and development: The resource curse at the micro, meso and macro levels. The Extractive Industries and Society 2 (2): 381-390.

Gilberthorpe, E., and D. Rajak. 2017. The anthropology of extraction: Critical perspectives on the resource curse. The Journal of Development Studies 53 (2): 186-204.

Grumiller, J. 2018. Upgrading potentials and challenges in commodity-based value chains: The Ivorian and Ghanaian cocoa processing sectors. Journal für Entwicklungspolitik 34: 15-45.

Gruss, B., and S. Kebhaj. 2019. Commodity terms of trade: A new database. IMF Working Papers, 19(21).

Gylfason, T., T.T. Herbertsson, and G. Zoega. 1999. A mixed blessing: Natural resources and economic growth. Macroeconomic Dynamics 3 (2): 204-225.

Harvey, D.I., N.M. Kellard, J.B. Madsen, and M.E. Wohar. 2010. The Prebisch-Singer hypothesis: Four centuries of evidence. Review of Economics and Statistics 92 (2): 367-377.

Headey, D. 2011. Rethinking the global food crisis: The role of trade shocks. Food Policy 36 (2): 136-146.

Hirschmann, A. 1981. Essays in trespassing. Cambridge: Cambridge University Press.

Humphreys, M., J.D. Sachs, and J.E. Stiglitz (eds.). 2007. Escaping the resource curse. New York: Columbia University Press.

IDB. 2020. Trade trends estimates-Latin America and the Caribeen. Inter-American Development Bank.

IEA. 2020. Oil market report-April 2020. IEA. https://www.iea.org/reports/oil-market-report-april -2020 .

IMF. 2020a. IMF Fiscal monitor 2020 - Chapter 1 policies to support people during the COVID-19 pandemic. Washington, DC: International Monetary Fund.

IMF. 2020b. World Economic Outlook 2020_Chapter 1. Washington, DC: International Monetary Fund.

Jacks, D.S. 2019. From boom to bust: A typology of real commodity prices in the long run. Cliometrica 13 (2): 201-220.

Kaplinsky, R., and M. Morris. 2016. Thinning and thickening: Productive sector policies in the era of global value chains. The European Journal of Development Research 28 (4): 625-645.

Lahn, G., and P. Stevens. 2018. The curse of the one-fits-all fix: Re-revaluation-What we know about extractives and economic development. In Extractive industries: The management of resources as a driver of sustainable development, ed. T. Addison and A. Roe, 93-113. Oxford: Oxford University Press.

MacDonald, A. 2020. COVID-19 mining impacts-mines reopening as restrictions ease. S\&P Global Market Intelligence. https://www.spglobal.com/marketintelligence/en/news-insights/research/covid 19-mining-impacts-mines-reopening-as-restrictions-ease.

Meyer, G. 2020. US to set caps on commodities speculators. Financial Times. https://www.ft.com/conte nt/ef4f6060-42b8-11ea-a43a-c4b328d9061c.

Morris, M., R. Kaplinsky, and D. Kaplan. 2012. "One thing leads to another"-Commodities, linkages and industrial development. Resources Policy 37 (4): 408-416.

Nissanke, M. 2012. Commodity market linkages in the global financial crisis: Excess volatility and development impacts. Journal of Development Studies 48 (6): 732-750.

Nissanke, M. 2017. The changing landscape in commodity markets and trade and implications for development. In Future Fragmentation Processes: Effectively Engaging with the Ascendancy of Global Value Chains, ed. J.-A. Keane, and R. Baimbill-Johnson. The Commonwealth, p. 26-46.

Nkurunziza, J.D., K. Tsowou, and S. Cazzaniga. 2017. Commodity dependence and human development. African Development Review 29 (S1): 27-41.

Ocampo, J.A. 2017. Commodity-led development in Latin America. International Development Policy 9 (9): 51-76.

Ocampo, J.A., and S. Griffith-Jones. 2007. A counter-cyclical framework for a development-friendly international financial architecture. UN Department of Economic and Social Affairs (DESA) Working Papers.

Ocampo, J.A., C. Rada, and L. Taylor. 2009. Growth and policy in developing countries: A structuralist approach. Growth and policy in developing countries. Columbia University Press.

OECD. 2020a. COVID-19 in Africa: Regional socio-economic implications and policy priorities. Paris: OECD.

OECD. 2020b. The impact of the coronavirus (COVID-19) crisis on development finance. Paris: OECD.

Prebisch, R. 1950. The economic development of Latin America and its principal problems. New York: United Nations.

Rodrik, D. 2018. New technologies, global value chains, and the developing economies, p. 30. 
Rosenstein-Rodan, P. 1961. Notes on the theory of the 'big push'. Economic Development for Latin America, pp. 57-81.

Rostow, W.W. 1960. The stages of economic growth: A non-communist manifesto. Cambridge, MA: Cambridge University Press.

Sachs, J.D., and A.M. Warner. 2001. The curse of natural resources. European Economic Review 45 (4-6): 827-838.

Sarraf, M., and M. Jiwanji. 2001. Beating the resource curse: The case of Botswana, 36. Washington, DC: World Bank.

Singer, H.-W. 1950. The economic development of Latin America and its principal problems. American Economic Review 40: 473-485.

Staritz, Cornelia, Susan Newman, Bernhard Tröster, and Leonhard Plank. 2018. Financialization and global commodity chains: Distributional implications for cotton in sub-saharan Africa. Development and Change 49 (3): 815-842. https://doi.org/10.1111/dech.12401.

Stiglitz, J. and J.Y. Lin., eds. 2013. The industrial policy revolution I: The role of government beyond ideology. Palgrave Macmillan UK (International Economic Association Series).

Tadesse, G., B. Algieri, M. Kalkuhl, and J. von Braun. 2014. Drivers and triggers of international food price spikes and volatility. Food Policy 47: 117-128.

Tröster, Bernhard. 2018. Commodity Price Stabilization - the need for a policy mix that breaks the vicious cycle of commodity dependence and price volatility. In: ÖFSE Policy Note 20. Vienna: Austrian Foundation for Development Research (ÖFSE).

Tröster, Bernhard, Cornelia Staritz, Jan Grumiller, and Felix Maille. 2019. Commodity dependence, global commodity chains, price volatility and financialisation: Price-setting and stabilisation in the cocoa sectors in Côte d'Ivoire and Ghana. Working Paper Nr. 62. Wien: Austrian Foundation for Development Research (ÖFSE).

UN DESA. 2020. Commodity exporters face mounting economic challenges as pandemic spreads. UN/ DESA Policy Brief \#60.

UN ECLAC. 2020a. Fiscal Panorama of Latin America and the Caribbean 2020. Fiscal policy amid the crisis arising from the coronavirus disease (COVID-19) pandemic, 159. Santiago.

UN ECLAC. 2020b. Measuring the impact of COVID-19 with a view to reactivation. Santiago.

UNCTAD. 2019a. Commodity dependence: A twenty-year perspective. Geneva: United Nations Conference on Trade and Development.

UNCTAD. 2019b. State of commodity dependence 2019. Geneva: United Nations Conference on Trade and Development.

UNCTAD and FAO, eds. 2017. Commodities and development report 2017: Commodity markets, economic growth and development. New York; Geneva.

van der Ploeg, F. 2011. Natural resources: Curse or blessing? Journal of Economic Literature 49 (2): 366-420.

van der Ploeg, R. 2016. Managing the crash in commodity prices. VoxEU.org. 24th December. https:// voxeu.org/article/managing-crash-commodity-prices.

van der Ploeg, F., and S. Poelhekke. 2009. Volatility and the natural resource curse. Oxford Economic Papers 61 (4): 727-760.

Van der Ploeg, F., and S. Poelhekke. 2017. The Impact of natural resources: Survey of recent quantitative evidence. The Journal of Development Studies 53 (2): 205-216.

von Arnim, Rudiger, Bernhard Tröster, Cornelia Staritz, and Werner Raza. 2018. Commodity price shocks and the distribution of income in commodity-dependent least-developed countries. Journal of Policy Modeling 40 (2): 434-451. https://doi.org/10.1016/j.jpolmod.2018.02.008.

von Braun, J., and M. Torero. 2009. Implementing physical and virtual food reserves to protect the poor and prevent market failure. IFPRI, p. 4.

Whitfield, L., O. Therkildsen, L. Buur, and A.M. Kjær. 2015. The politics of African industrial policy by Lindsay Whitfield. Cambridge Core.

World Bank. 2020. A shock like no other: The impact of COVID-19 on commodity markets. Washington, DC: World Bank.

Publisher's Note Springer Nature remains neutral with regard to jurisdictional claims in published maps and institutional affiliations. 